\title{
Students' Problems in Completing Sentence by Using Linking Be at First Grade of SMPN 1 Kerinci
}

\author{
Efa Silfia \\ Program Study Pendidikan Bahasa Inggris FKIP UNBARI \\ email: efasilfia28@gmail.com
}

\begin{abstract}
One of the rules of grammar carries out important rule that is using simple linking be. Linking Be shows existence or, as the case may be, nonexistence. This research was aimed to find out the students' problems in completing sentence by using linking be at first grade of SMPN 1 Kerinci Academic Years 2018/2019 and the causes of the students' problems in completing sentence by using linking be at first grade of SMPN 1 Kerinci Academic Years 2018/2019. The design of this research was descriptive research. The population was at the grade VII students of SMPN 1 Kerinci. There were 156 students which consisted of 7 classes as the population. This population was tested by using Bartlett test to make homogeneity. Then, the sample was VII B. The instruments were given grammar test in multiple choices as quantitative data and took interview as qualitative data. Moreover, it was also proven by the result of the total percentage of the students. There were $47 \%$ students who got very good, $26 \%$ students got good, $21.7 \%$ students got fair, $4.3 \%$ got weak and no student got poor. And mean score of the students was 75.6. Based on interview to students, there were some problems faced by the students' in completing sentence by using linking be. They only made mistake in some cases. But they have learned and known which one to be is when they were asked to make sentence. Based on the result of data analysis, it was concluded that generally the students' students' problems in completing sentence by using linking be at first grade of SMPN 1 Kerinci was good.
\end{abstract}

Keyword: problems, sentence, linking be

Abstrak: Salah satu aturan tata bahasa yang merupakan aturan penting yaitu menggunakan penghubung sederhana "linking be". Likning Be menunjukkan keberadaan atau, sebagaimana adanya, ketidakadaan. Penelitian ini bertujuan untuk mengetahui masalah siswa dalam menyelesaikan kalimat dengan menggunakan linking be di kelas satu SMPN 1 Kerinci Tahun Akademik 2018/2019 dan penyebab masalah siswa dalam menyelesaikan kalimat dengan menggunakan linking be di kelas satu SMPN 1 Kerinci Tahun Akademik 2018/2019. Rancangan penelitian ini adalah penelitian deskriptif. Populasinya adalah siswa kelas VII SMPN 1 Kerinci. Ada 156 siswa yang terdiri dari 7 kelas sebagai populasi. Populasi ini diuji dengan menggunakan uji Bartlett untuk menguji homogenitas. Kemudian, sampelnya adalah VII B. Instrumen diberikan tes tata bahasa dalam pilihan ganda sebagai data kuantitatif dan mengambil wawancara sebagai data kualitatif. Selain itu, itu juga dibuktikan dengan hasil persentase total siswa. Ada 47\% siswa yang mendapat nilai sangat baik, 26\% siswa mendapat nilai baik, 21,7\% siswa mendapat nilai wajar, 4,3\% siswa lemah dan tidak ada siswa yang miskin. Dan nilai rata-rata siswa adalah 75,6. Berdasarkan wawancara dengan siswa, ada beberapa masalah yang dihadapi oleh siswa dalam menyelesaikan kalimat dengan menggunakan linking be. Mereka hanya melakukan kesalahan dalam beberapa kasus. Tetapi mereka telah belajar dan mengetahui yang mana yang akan menjadi ketika mereka diminta untuk membuat kalimat. Berdasarkan hasil analisis data, dapat disimpulkan bahwa secara umum masalah siswa dalam menyelesaikan kalimat dengan menggunakan linking be di kelas satu SMPN 1 Kerinci adalah baik.

Kata kunci: masalah-masalah, kalimat, linking be

\section{PENDAHULUAN}

Grammar is a key for learning English Language because grammar help us to study English deeply in writing and speaking. It is sometimes defined as " the words are put together to make correct sentence" (Azar, 1993:40). It is a set of rules that defined how words (or parts of words) are combined or changed to form acceptable units of meaning within a language. It is one of important aspects in writing sentence, the students who want to write well should master grammar in order to make good sentence. Further, Hidayati (2011:11) also points out that grammar is the way in which words change themselves and group together to make sentences. The grammar of language is what happens to words when they become plural or negative, or what order is used when we make question or join two clauses to make one sentence. So, grammar is a description of the rules for forming sentences, including an account of the meaning that these forms convey

Besides, grammar can be part of poetry and stories, then knowing about grammar means to find out all language and all dialects follow grammatical patterns. In learning grammar, there are many kinds of the rules and elements how to make good sentence. Related to that statement, it is important to make sentence having the meaning by using some components. According to Sam (2003:3), "A sentence is a grammatical unit of one or more words that starts with a capital letter and ends with a full stop or its equal (! or ?) and 
expresses an independent statement." In academic writing, the sentence is the level at which you begin to make sense in your writing, and where you can make grammatical mistakes. A sentence is a linguistic unit consisting of one or more words that are grammatically linked. A sentence can include words grouped meaningfully to express a statement, question, exclamation, request, command or suggestion.

One of them carries out important rule that is using linking "be". Linking be is important as the basic rule for the students to make and use sentences to communicate in daily life especially in telling something in the past. In grammar, linking be refers to serves to join the grammatical subject of the sentence with either an adjective or a noun to describe or identify the subject.

Based on observation and information obtained from the English teacher at SMPN 1 Kerinci, it was found that many students still had dificulties in mastering grammar, especially in using linking be. It is included important as the basic rule for the students to make and use sentences to communication in daily life. Besides that, the students can identify and tell activity based on situation and condition. In this case, students often did not understand how to use to be. It is caused the students did not understand what their teacher had taught abouthot to use to be in sentence, they can not know what to be is used for some subjects. For example, the teacher asked the student to complete sentence by using to be correctly, like "you......a farmer." The student filled to be "is" for complete this sentence. Eventhough, the correct answer is using to be "are". They still didn't know what to be should be taken in every subject pronoun.

Linking be refers to The verb to be shows existence or, as the case may be, nonexistence. This existential feature of the be word prompted Shakespeare's Hamlet to ask: "To be or not to be, that is the question." The verb to be also shows that something takes place, happens, or will occur in the future, as in: The meeting is next week. It shows that something occupies a particular place, as in: The book is on the shelf.

Moreover, the problems that found in the school especially at first grade of SMPN 1 Kerinci were about completing sentence. They got difficulties to complete sentence well. While, sentence consists of subject, predicate and complement. But the students still can not understand what they should make sentence with grammar well. This situation is caused the students don't know tense and are not taught grammar correctly. They can not arrange sentence based on tense and rule.

Having these problems, the researcher had to do the research about "Students' Problems in Completing Sentence by Using Linking Be at first grade of SMPN 1 Kerinci Academic Years 2018/2019.”

\section{RESEARCH METHOD}

In conducting this research, the research used descriptive method. Descriptive research involves collecting data in order to answer question concerning the current status of the subject of the study (Gay, 2002:11). According to Sudijono (2009:76) states that descriptive research is the research that collects data that is held by doing observation and noting systematically of the phenomena that is being made as the object of the research.

This research was described the Students' Problems in Completing Sentence by Using Linking Be and the causes of problems at first grade of SMPN 1 Kerinci Academic Years 2018/2019. In this research, the research took all of first grade students at SMPN 1 Kerinci. There were seven classes.

In this research, the researcher used cluster sampling technique. Cluster sampling technique randomly selects groups, not individuals. According to Gay and Airasian (2009: 124) states "cluster sampling is randomly selected group, not individual". In selecting the sample, the researcher used lottery then write seven small papers with different number.

Before considering the sample, the researcher calculated homogeneity by using Bartlett test. The researcher followed some steps in choosing sample to make sure the sample that used in generalization for all population members. Steps in choosing sample that the researcher used were:

1. The researcher collected students' quiz score at first grade of SMPN 1 Kerinci, then calculates mean to know homogeneity.

2. Homogeneity variance test is using Bartlett test. Score that needed for Bartlett testing

$$
H_{0}: \sigma_{1}^{2}=\sigma_{2}^{2}=\cdots=\sigma_{k}^{2}, \text { Sudjana in Farlan }(2014: 19)
$$




\begin{tabular}{|c|c|c|c|c|c|}
\hline Sample of & Dk & $1 / \mathbf{d k}$ & $S_{i}^{2}$ & $\log S_{i}^{2}$ & dk $\log S_{i}^{2}$ \\
\hline 1 & $n_{1}-1$ & $1 /\left(n_{1}-1\right)$ & $S_{1}^{2}$ & $\log S_{1}^{2}$ & $n_{1}-1 \log S_{1}^{2}$ \\
\hline 2 & $n_{2}-1$ & $1 /\left(n_{2}-1\right)$ & $S_{2}^{2}$ & $\log S_{2}^{2}$ & $n_{2}-1 \log S_{2}^{2}$ \\
\hline $\mathrm{K}$ & $n_{k}-1$ & $1 /\left(n_{k}-1\right)$ & $S_{k}^{2}$ & $\log S_{k}^{2}$ & $n_{k}-1 \log S_{k}^{2}$ \\
\hline Sum & $\Sigma\left(n_{i}-1\right)$ & $\sum\left(\frac{1}{\left(n_{i}-1\right)}\right)$ & - & - & $\Sigma\left(n_{i}-1\right) \log S_{k}^{2}$ \\
\hline
\end{tabular}

From table calculated score that need, that is:

1) Calculating variance from all population by formula:

$$
S^{2}=\frac{\sum\left(n_{i}-1\right) S_{i}^{2}}{\Sigma\left(n_{i}-1\right)}
$$

2) Calculating Barlett score unit:

$B=\left(\log S^{2}\right) \Sigma\left(n_{i}-1\right)$

3) Using statistic Chi-quadrate by formula:

$X^{2}=(1 n 10)\left\{B-\Sigma\left(n_{i}-1\right) \log S_{i}^{2}\right\}$ by $1 n 10=9,488$

Score $X_{\text {hitu橙 }}^{2}$ than with $X_{\text {table }}^{2}$, with testing criteria unused $H_{o}$ if : $X^{2} \geq X_{(1-\alpha)(k-1)}^{2}$, where $X_{(1-\alpha)(k-1)}^{2}$ got from distribution chi-quadrate by opportunity $(1-\alpha)$ and $\mathrm{dk}=(\mathrm{k}-1)$.

After seven classes homogeneity and to get sample class the researcher used cluster sampling techniques.

The researcher did the research at SMPN 1 Kerinci. It was taken about two weeks. The test was done in first week and the interview was done in second week. The instrument of this research used quantitative and qualitative instrument. In quantitative, it was used grammar test. This test was used to collect the students' data. The researcher provided students with randomly word in sentence by using linking be. Then, the student completed this sentence well. In this instrument, the students were given 30 sentences. They contains linking be "is, am, are, was and were". The researcher gave the score for the correct answer by using the formula of students' real test. One correct answer was given score 1, and incorrect answer was 0 . Before conducting the test, the reseracher does try out test to get validity and reliability of the items.

While in qualitative, the interview was used to know more about the students' condition learning and about the causes of students' problems in completing sentences by using linking be at first grade students at SMPN 1 Kerinci. The researcher chose 5 students to be interviewed.

In collecting the data, the researcher also used quantitative and qualitative data. In quantitative data, the test was administrated to describe the students' problems in completing sentence by using linking be and the causes of problems at first grade of SMPN 1 Kerinci. The researcher gave students time to do test about 40 minutes. After that, the researcher collected the result of the test. Then, the researcher gave the score for students' sheet. Finally, the researcher gave mark of the result test objectively. While, The researcher used qualitative data to collect the data that is interview. The interview was done after the students have finished grammar test. The researcher gave 6 questions for the students. The researcher takes 5 students be interviewed. The interview was given to know what problems that the students behave and the causes of students'problems. They were from grade VII B of SMPN 1 Kerinci

Moreover, in analyzing the data, the research used these steps below:

a. The researcher counted the total score of each student in grammar test.

b. The researcher calculated the percentage of students' score in grammar test.

c. The researcher classified the students' score

Then, Qualitative data will be analyzed the data taken from interview at the end of reading test. And she also makes a conclusion what problems that the students behave and the causes of students'problems. As Gay (2000: 239) propose that: six steps in analyzing qualitative data. They are:

a. Data Managing

The researcher manages the data from the interview that has been collected during the research and then organized the data. The researcher takes the data from an interview. Then she must put the data in a form that facilitated analysis.

b. Reading and Memoing 
In this step of reading and memoing for the interview data, the researcher listens to the interview's result of each student and notes the data based on the question addressed to them. The researcher listens to the interview several times until she gets the data needed and made an example of the transcription.

c. Description

After reading the data, the result will be got the problems that the students behave and the causes of students in completing sentence by using linking be, the researcher describes the students' responses.

d. Classification

In this step, the researcher classifies the interview's result based on their answer.

e. Interpretation

In this next step of data analysis, the researcher interprets the data based on their classification above. After that, the researcher also interprets the data in a more detail way by seeing them based on the students behave and the causes of students completing sentence by using linking be.

f. Writing report

The final stage is writing of a report that describes the study and its finding. The process of writing report describing researcher's study will inevitably force her to reexamine her data interpretations. Then, they are concluded based on the result of interview results.

\section{THE RESULT OF RESEARCH}

\section{The Students' Problems in Completing Sentence by Using Linking Be at first grade of SMPN 1 Kerinci Academic Years 2018/2019}

The purpose of this study was to find out the students' problems in completing sentence by using linking be. The data were collected by giving grammar test. Before giving the test, the students were given the try-out test at VII C. The test was conducted on Wednesday, 19 September 2018. They were 21 students. The test items consisted 30 items, and it aimed to get the validity and the reliability of the test. To see the validity of the test, the researcher counted the items difficulties and the items of index discrimination. The researcher calculated the item of difficulties to know which number of item was easy, moderate and difficult.

Based on the result of calculation, the researcher deleted the item numbers $3,5,7,10,12,14,18,20$, 21 , and 26, because these items did not fulfill the criteria of good and satisfactory questions. Therefore, the researcher just used 20 items for test, they were the item numbers $1,2,4,6,8,9,11,13,15,16,17,19,22$, $23,24,25,27,28,29$ and 30.

In getting the reliability of the test, the researcher used the Person Product Moment. And the result was $r_{x y}=0.838$. It meant that the degree of coefficient correlation of the try-out was categorized as high correlation, and the test was reliable.

Having the validity and reliability, there were students's score in completing sentence by using linking be. The result of test was no students who got very good, good, fair category. There were 5 students who got weak category and 16 students who got poor category. Moreover, the researcher got the mean of the students score 34.6. It can be pointed that most of the students had problems in completing sentence by using linking be.

From the data of students' grammar test in try out, the researcher calculated the percentage of the students' score. Here was the result of the calculation:

Table 1 Percentage of Try out Test

\begin{tabular}{cllcc}
\hline No & & Interval & Frequency & Percentage \\
\hline 1 & $80-100$ & 0 & $0 \%$ \\
2 & $66-79$ & 0 & $0 \%$ \\
3 & $56-65$ & 0 & $0 \%$ \\
4 & $46-55$ & 5 & $23.8 \%$ \\
5 & $0-45$ & 16 & $76.2 \%$ \\
\hline
\end{tabular}

Based on the table above, the data showed that there were no students got very good, good, and fair score, but there were $23.8 \%$ students got weak score and $76.2 \%$ students got poor score. So that, the researcher concluded that students still got problems in completing sentence by using linking. 
After conducting try out test, the researcher did the real test to find out students' problem in completing sentence by using linking be. She chose VII B as the sample of the research. They consisted of 23 students. The sample was chosen by using cluster sampling technique. Before choosing the sample, she did Bartlett test to see homogenity of the sample. The researcher obtained the quiz's score to be the data analysis. Then, she got the sample at VII B.

To get the students' problems, the researcher conducted real test at VII B. The test formed multiple choice that consisted of 20 items. The research got the result of the test that described the result of the students' test in completing sentence by using linking be. The test was conducted on Tuesday, 29 September 2015. The test required the students to identify and analyze the students' problems in completing sentence by using linking be.

Based on the result of students' score in the test, the researcher found that the highest score was 90 gained by 4 students and the lowest score was 55 gained by 1 student. The researcher calculated the mean score of the students. It was 75.6. And also the researcher presented the classification of students' score on percentage of category.

Table 2 Percentage of Students' Score in Real Test

\begin{tabular}{cllcc}
\hline No & & Interval & Frequency & Percentage \\
\hline 1 & $80-100$ & 11 & $47.8 \%$ \\
2 & $66-79$ & 6 & $26 \%$ \\
3 & $56-65$ & 5 & $21.7 \%$ \\
4 & $46-55$ & 1 & $4.3 \%$ \\
5 & $0-45$ & 0 & $0 \%$ & $0 \%$ \\
\hline
\end{tabular}

Based on the table above, the data showed that there were $47 \%$ students who got very good, $26 \%$ students got good, $21.7 \%$ students got fair, $4.3 \%$ got weak and no student got poor. So that, the researcher concluded that students' problems in completing sentence by using linking be was poor. Most of the students had no problems in completing sentence by using linking be.

Based on the result of data analysis, the researcher found that the students of VII C still got problems in completing sentence by using linking be. It was proved when the researcher did try out. They got problems in answering the questions given by the researcher about linking be. The students didn't know what tobe was going on in the questions. For example, the question was ".... your children driving home last weekend?". Most of the students answered with tobe "are". Eventhought the correct answer was used tobe "were". It also could be seen in question like "The girls .......... laughing really loud." The students often answered by using tobe "is", but the correct tobe was "are".

Furthermore, most of the students still made problem in answering the questions in using simple past and plural noun. Because most of the students were confused in completing and choosing correct tobe for these questions. It can be seen by the fact that most of students got weak and poor in try out test. It indicated that the students had problems in completing sentence by using linking be at grade VII C of SMP N 1 Kerinci.

Next, having this result of the real test, the researcher found that students had good score in completing sentence by using linking be. It was conducted at grade VII B. Most of students had good score in the test. They have known the correct tobe for completing sentence. The students' problems in answering questions were less. It could be concluded that students at grade VII B of SMP N 1 Kerinci.had understanded about each linking be and had no problems in completing sentences.

\section{The Causes of Students' Problems in Completing Sentence by Using Linking Be at first grade of SMPN 1 Kerinci Academic Years 2018/2019}

After finding out the result of students in grammar test above, the researcher conducted the interview to the students at grade VII B of SMPN 1 Kerinci. It was done on Wednesday, 26 September 2018. The researcher took 5 students involved in interview. Based on the result, the researcher randomly chose in the data of this research. The result of interview would be known the causes of students' problems in completing sentence by using linking be. 
Based on the result of the interview, the students had same causes in problems of completing sentence by using linking be/tobe (is, am, are, was, were). Most of them got difficulties in completing sentence by using present tobe. And then they made mistake in same sentences. It meant that the students had learned and known which one tobe is, but when they were asked to make sentence, they couldn't. Moreover they also could answer the questions in the test, but if they were asked to interview in making sentence, they couldn't. It could be seen that the students of VII B still couldn't make sentence by using linking be orally, but they could answer the question only in completing sentence.

\section{CONCLUSION}

Based on findings, it can be concluded that the result of the test was indicated that students' problems in completing sentence by using linking be was good category. It was based on the mean of the students' score in the test, it was 75.6. And from the data of interview, it was indicated that the causes of problems in completing sentence by using linking be at grade VII B of SMPN 1 Kerinci had still a little difficulties to make sentence by using tobe in present (is, am, are) And also they knowed and could mention the linking be like is, am, are, was, were.

\section{REFERENCE}

Arikunto, Suharsimi. 2006. Prosedur Penelitian: Suatu Pendekatan Praktek. Jakarta: Rineka Cipta.

Azar. S. Betty. 1993. English Grammar. Jakarta: Binapura Aksara.

Gay, R.L and Airisian, Peter. 2002. Ecducational Research: competencies for analysis and application sixth edition. New Jersey: Prentice Hall.

Gay, R.L and Airisian, Peter. 2009. Ecducational Methodology. New Jersey: Prentice Hall.

Haryono. 2008. Grammar in EFL. Jakarta: Binapura Aksara.

Hidayati, Puji. 2011. The Use of Card Sort to Improve Students' Understanding on simple past tense. Tegal: Skripsi

Kursiman.2008. Improving students' writing ability in finding linking verb by using mapping at grade XI of SMAN 2 Kerinci. Skripsi. STKIPM SPN.

Sam, Aliyath. 2003.Sentence. Retrieved from http://sentence.html on 10 September 2018.

Sepriawan. 2013. Improving students' ability in linking verb “to be” through group investigation at grade XI of SMAN 4 Kerinci. Skripsi. STKIPM SPN.

Sudijono, Anas. 2009. Pengantar Evaluasi Pendidikan. Jakarta: PT. Raja Grafindo Persada. 